\title{
Meningkatkan Kemampuan Sains dengan Metode Eksperimen Mencampur Warna di KB Widya Purwacaraka Pati
}

\author{
Ana Reknowati dan Sumiyati \\ Institut Pesantren Mathali'ul FalahPati \\ Email: ana.ipmafa@gmail.com
}

\begin{abstract}
The purposes of this research is to know: (1) The ability of children's science in KB Widya Purwacaraka Cabak, and (2) the effect of the experimental method of mixing the color to children's science skills in KB Widya Purwacaraka Cabak. This type of research includes Classroom Action Research. The results of the study concluded that: (1) The ability of children's science in KB Widya Purwacaraka Cabak Pati before the action is still low. The level of children's science skills that are included in the category of Emerging (MM) and Not Emerging (BM) is $64.52 \%$. (2) The use of mixed color experimental methods can improve children's science skill. This is shown from: (a) Increasing the ability of children science including Very Good Developing (BSB) and Expectancy Developing (BSH) from the pre cycle, cycle I and cycle II, that is pre new cycle of $35,48 \%$, cycle I become $67.74 \%$ and cycle II increased again to $93.55 \%$. (2) Increasing the average score of children's science skills from pre cycle, cycle I and cycle II, that is pre-cycle 2 which belongs to the Emerging (MM) category, cycle I increases to 3 which belongs to Expectancy Developing (BSH) category, and cycle II the average score increased again to 3 and included the category Expectancy Developing (BSH).
\end{abstract}

Keywords: Ability of Science, Experimental Method, Mixing Color 


\section{PENDAHULUAN}

Pada hakikatnya pendidikan anak usia dini menyajikan konsep belajar sambil bermain. Hal ini sesuai dengan karakteristik mereka yang bersifat aktif dalam melakukan berbagai eksplorasi terhadap lingkungannya. Pembelajaran diarahkan pada pengembangan dan penyempurnaan potensi kemampuan yang dimiliki seperti kemampuan bahasa, sosial, emosional, motorik, spiritual dan intelektual (E. Mulyasa, 2012). Hal ini juga sesuai dengan pendapat Sumiyati yang mengemukakan bahwa potensi diri yang telah dimiliki oleh anak harus dikembangkan sedini mungkin karena apabila potensi itu tidak dapat direalisasikan dan dikembangkan, maka sama artinya anak tersebut telah kehilangan periode emas dalam hidupnya (Sumiyati, 2014). Salah satu potensi tersebut di antaranya adalah kemampuan sains anak usia dini.

Hakikat pengembangan sains di TK/RA adalah kegiatan belajar yang menyenangkan dan menarik dilaksanakan sambil bermain melalui pengamatan, penyelidikan dan percobaan untuk mencari tahu atau menemukan jawaban tentang kenyataan yang ada di dunia sekitar (Yuliani Sujiono, dkk, 2008). Dengan demikian, secara umum permainan sains di TK/RA bertujuan agar anak mampu secara aktif mencari informasi tentang apa yang ada di sekitarnya. Untuk memenuhi keingintahuannya melalui eksplorasi di bidang sains anak mencoba memahami dunianya melalui pengamatan, penyelidikan dan percobaan.

Kegiatan pengenalan sains untuk anak Taman KanakKanak/Raudlatul Athfal (TK/RA) lebih menekankan proses daripada produk. Sains memungkinkan anak melakukan eksplorasi terhadap berbagai benda, baik benda hidup maupun benda tidak hidup yang ada di sekitarnya. Anak akan menemukan gejala benda dan gejala peristiwa yang ada di alam sekitarnya. Sains juga melatih anak menggunakan pancaindranya untuk mengenal berbagai gejala benda dan gejala peristiwa. Anak memperoleh pengetahuan baru hasil interaksinya dengan berbagai benda yang ada di sekitarnya. Pengetahuan yang diperoleh akan berguna sebagai modal berpikir (Slamet Suyanto, 2008).

Sehubungan dengan itu, dalam proses pembelajaran sains guru dituntut untuk menciptakan suasana yang menyenangkan agar anak aktif bereksplorasi, bertanya dan mengemukakan gagasan. Hakikat belajar merupakan proses aktif dari anak 
didik dalam membangun pengetahuan. Partisipasi aktif dari anak didik sangat penting dalam rangka pembentukan generasi yang kreatif sehingga diperlukan penerapan metode pembelajaran yang tepat.

Penerapan metode yang tepat akan turut menentukan efektivitas dan efisiensi pembelajaran (E. Mulyasa, 2013).Pembelajaran yang efektif salah satunya ditandaidengan tumbuhnya interaksi edukatif antara guru dan siswa. Siswa secara aktif terdorong untuk melakukan kegiatan belajar dengan penuh semangat. Dalam Undang-undang Nomor 20 Tahun 2003 tentang Sistem Pendidikan Nasional Pasal 1 disebutkan bahwa pembelajaran adalah interaksi peserta didik dengan pendidik dan sumber belajar pada suatu lingkungan belajar (Departemen Agama Rl, 2006). Jadi dalam pembelajaran dapat terlaksana apabila ada interaksi antara peserta didik dan pendidik serta adanya sumber belajar.

Namun hal tersebut belum terlaksanakan di KB Widya Purwacaraka Cabak. Guru dalam melaksanakan pembelajaran sains masih disampaikan secara konvensional. Guru lebih banyak menerangkan materi sains dengan ceramah, yang mengharapkan siswa diam, duduk dan mendengarkan saja. Guru juga belum menggunakan metode pembelajaran yang melibatkan anak seacara aktif untuk bereksplorasi. Guru juga belum memanfaatkan media atau lingkungan yang ada di sekitar siswa. Media yang digunakan hanya terbatas kapur tulis, kertas dan pensil secara monoton. Ini menyebabkan kegiatan pembelajaran sains yang dilaksanakan oleh guru membosankan bagi siswa, sehingga minat dan motivasi belajar siswa dalam mempelajari sains rendah. Hal ini menyebabkan kemampuan sains siswa juga rendah (belum maksimal), (Hasil Observasi Pembelajaran di KB Widya Purwacaraka Cabak Tlogowungu Pati, 8 November 2016).

Dari masih rendahnya kemampuan sains di atas, guru dalam mengajarkan sains anak dapat ditempuh melalui pembelajaran yang menyenangkan bagi anak, agar materi yang disampaikan dapat dipahami dan dikuasai oleh anak di antaranya melalui kegiatan eksperimen mencampur warna.

\section{METODE}

Penelitian ini merupakan penelitian tindakan kelas yang mengambil lokasi di KB Widya Purwacaraka Cabak Tlogowungu Pati. Penelitian Tindakan Kelas ini dilaksanakan 
pada bulanNovember $2016 \mathrm{~s} / \mathrm{d}$. Februari 2017.Subjek dalam penelitian tindakan kelas ini adalah siswa KB Widya Purwacaraka Cabak Tlogowungu Pati.yang berjumlah 31 siswa.Peneliti dalam penelitian tindakan kelas melibatkan guru pendamping sebagai kolaborator penelitian bertugas sebagai pengamat dan untuk berdiskusi dalam refleksi.

Dalam penelitian ini, data yang peneliti kumpulkan berupa informasi tentang proses pembelajaran melalui metode eksperimen mencampur warna, kemampuan sains, dan kemampuan peneliti sebagai guru dalam menyusun Rencana Kegiatan Harian serta pelaksanaan pembelajaran di kelas. Adapun sumber data dalam penelitian ini meliputi: (1) informan atau nara sumber, yaitu siswa, guru, dan kolaborator penelitian; (2) tempat dan peristiwa berlangsungnya kegiatan pembelajaran dengan metode eksperimen, dan (3) dokumen Rencana Kegiatan Harian, hasil kemampuan sains anak, dan buku penilaian.

\section{HASIL PENELITIAN}

Pra siklus merupakan kegiatan awal yang peneliti laksanakan sebelum tindakan. Kegiatan pra siklus ini peneliti laksanakan untuk mengetahui kondisi awal dari kemampuan sains anak di KB Widya Purwacaraka Cabak. Kegiatan pra siklus ini peneliti laksanakan pada hari Kamis, 1 Desember 2016. Langkahlangkah kegiatan pembelajaran yang peneliti lakukan dalam pra siklus ini adalah sebagai berikut:

Pada awal kegiatan awal siswa diajak untuk berbaris rapi di depan kelas. Kemudian dilanjutkan dengan masuk ke dalam kelas. Setelah itu guru mengucapkan salam, doa sholawat, mengabsen siswa. Setelah itu siswa diminta untuk menirukan lafal surat an-Nas. Kemudian setelah selesai siswa diajak bernyanyi lagu "Air"

Guru dalam kegiatan inti ini menyampaikan materi secara lisan untuk membicarakan tentang air yang diminum. Kemudian guru menjelaskan tempat air, seperti ember, botol, maupun panci. Setelah itu, guru menceritakan bentuk air sesuai wadahnya seperti dalam gambar. Kemudian guru menyebutkan posisi benda yang terapung dan tenggelam.

Anak-anak dalam kegiatan istirahat melakukan beberapa kegiatan, di antaranya adalah makan bekal bersama. Kegiatan 
ini dimulai dengan mencuci tangan terlebih dahulu, berdoa sebelum dan sesudah makan. Setelah selesai, anak-anak dipersilahkan untuk bermain di halaman sekolah. Diakhir pembelajaran guru mengulas materi, menyampaikan pesanpesan kepada anak. Setelah itu, anak-anak berdoa dan pulang.

Kegiatan pembelajaran pra siklus sebagaimana di atas, guru dalam melaksanakan pembelajaran sains masih disampaikan secara konvensional. Guru lebih banyak menerangkan materi sains dengan ceramah, yang mengharapkan siswa diam, duduk dan mendengarkan saja.

Guru juga belum memanfaatkan media atau lingkungan yang ada di sekitar siswa. Ini menyebabkan kegiatan pembelajaran sains yang dilaksanakan oleh guru membosankan bagi siswa, sehingga minat dan motivasi belajar siswa dalam mempelajari sains rendah. Hal ini menyebabkan kemampuan sains siswa juga rendah (belum maksimal). Secara rinci hasil observasi tentang kemampuan sains anak pada pra siklus ini akan peneliti uraikan pada tabel berikut:

Tabel 4.1

Kemampuan Sains Anak Pra Siklus

\begin{tabular}{|c|c|c|c|}
\hline Skor & Kategori & Jumlah & Persentase \\
\hline 4 & BSB & 2 siswa & $6,45 \%$ \\
\hline 3 & BSH & 9 siswa & $29,03 \%$ \\
\hline 2 & MM & 12 siswa & $38,71 \%$ \\
\hline 1 & BM & 8 siswa & $25,81 \%$ \\
\hline \multicolumn{2}{|c|}{ Total } & 31 siswa & $100 \%$ \\
\hline
\end{tabular}

Berdasarkan tabel 4.1 tentang kemampuan sains yang dicapai oleh anak pada pra siklus di atas dapat dijelaskan sebagai berikut:

1. Kemampuan sains anak yang termasuk dalam kategori Berkembang Sangat Baik (BSB) sejumlah 2 siswa atau sebesar 6,45\%.

2. Kemampuan sains anak yang termasuk dalam kategori Berkembang Sesuai Harapan (BSH) sejumlah 9 siswa atau sebesar $29,03 \%$. 
3. Kemampuan sains anak yang termasuk dalam kategori Mulai Muncul (MM) sejumlah 12 siswa atau sebesar $38,71 \%$.

4. Bahwa kemampuan sains anak yang termasuk dalam kategori Belum Berkembang (BB) sejumlah 8 siswa atau sebesar $25,81 \%$.

Dengan demikian, nilai rata-rata kemampuan sains anak pada pra siklusadalah sebesar 2. Berdasarkan dari interval kategori, skor rata-rata sebesar 2 adalah termasuk kategori Mulai Muncul (MM).

Berdasarkan dari kondisi awal (pra siklus)dapat disimpulkan terdapat permasalahan dalam pembelajaran sains di kelas yang peneliti teliti. Guru dalam melaksanakan pembelajaran sains masih dilaksanakan secara konvensional. Guru lebih banyak menerangkan materi sains dengan ceramah, yang mengharapkan siswa diam, duduk dan mendengarkan saja. Guru juga belum memanfaatkan media atau lingkungan yang ada di sekitar siswa. Media yang sering digunakan hanya terbatas pada penggunaan kapur tulis, kertas dan pensil secara monoton. Ini menyebabkan kegiatan pembelajaran sains yang dilaksanakan oleh guru membosankan bagi siswa, sehingga minat dan motivasi belajar siswa dalam mempelajari sains rendah.

Dari permasalahan tersebut, kemudian peneliti melakukan refleksi. Dalam refleksi tersebut, guru dalam pembelajaran sains yang dilaksanakan harus menekankan proses daripada produk yang tertuang dalam suatu rencana tindakan penelitian untuk siklus I dengan menyusun skenario pembelajaran.

Tahap awal yang peneliti laksanakan dalam melaksanakan tindakan siklus I ini adalah melaksanakan perencanaan. Dalam skenario ini mulai dicoba penerapan metode eksperimen mencampur warna dalam tema air, api, udara / Air anugerah Allah.

Kegiatan yang peneliti laksanakan dalam perencanaan ini adalah sebagai berikut:

1. Menyusun Rencana Kegiatan Harian (RKH) yang disesuaikan dengan permasalahan pada pra siklus.

2. Merancang dan membuat lembar observasi proses pembelajaran dan hasil belajar sains siswa.

3. Merancang dan membuat instrumen evaluasi. 
Setelah melaksanakan tahap perencanaan, kemudian dilanjutkan dengan tahap berikutnya, yaitu tahap pelaksanaan. Dalam tahap pelaksanaan siklus I ini, peneliti laksanakan melalui 3 kali pertemuan, yaitu: pertemuan 1 dilaksanakan pada hari Senin, 16 Desember 2016, pertemuan 2 hari Senin, 2 Januari 2017 dan pertemuan 3 hari Sabtu, 7 Januari 2017 dengan alokasi waktu mulai pukul 07.00-10.30 WIB di KB Widya Purwacaraka Cabak dengan tema air, api dan udara sub tema air anugerah Tuhan.

Pada tahap pijakan awal main, Kemudian guru menarik perhatian siswa dengan mengajak siswa untuk menyanyikan lagu "Air": Selanjutnya guru meminta siswa untuk mengikuti pembelajaran tema air, api, dan udara dengan kegiatan bermain air.

Dalam melaksanakan kegiatan inti pada siklus I ini terdiri dari tiga pertemuan. Adapun langkah-langkahnya sebagai berikut:

1. Guru di awal pelaksanaan kegiatan ini bercerita tentang "IImuwan" atau "Peneliti".Setelah peneliti bercerita kepada anak, peneliti mengajak anak untuk menyebutkan namanama benda yang digunakan untuk tempat air. Guru bertanya jawab tentang tempat-tempat air seperti: gelas, cangkir, dan ember.

2. Setelah itu, guru mengajak anak-anak untuk berkumpul di sentra yang sudah disediakan dengan duduk melingkar. Guru menjelaskan bahwa dalam kegiatan di sentra ini, anak-anak boleh memilih kegiatan yang disukai dan setelah selesai bisa menuju ke kegiatan yang lain. Jenis kegiatan yang ada terdiri dari tiga kegiatan, yaitu: 1) menuangkan air ke dalam wadah, 2) menghitung volume air dalam ember, dan 3) mencampur warna.

3. Untuk kegiatan jenis pertama, anak-anak duduk melingkari wadah seperti gelas, panci, mangkuk, dan ember. Setelah semua siswa melingkari wadah-wadah tersebut, guru mengajak anak untuk menuangkan air ke dalam wadah. Dimulai anak diajak untuk menuangkan air ke dalam gelas secara bergantian. Setelah selesai, kemudian anak diajak lagi untuk menuangkan air ke dalam Panci. Setelah selesai, anak diajak lagi untuk menuangkan air ke dalam mangkuk. Kemudian setelah itu, anak diajak untuk menuangkan air ke dalam ember. Kegiatan tersebut dilakukan secara berulangulang dengan dipandu oleh guru.

4. Selanjutnya pada jenis kegiatan kedua, menghitung volume air dalam ember. Anak-anak disuruh untuk mengambil air 
dari ember dengan media spons untuk dimasukkan ke dalam wadah botol air minum. Setelah wadah botol air minum terisi penuh, guru menanyakan kepada masingmasing siswa berapa kali spons yang dibutuhkan untuk mengisi botol air tersebut.

5. Untuk kegiatan ketiga, anak-anak melakukan percobaan pencampuran warna dengan cara memasukkan pewarna buatan. Kegiatan ini dimulai dengan memasukkan dua warna, yaitu merah dengan biru untuk dicampur ke dalam dalam air yang berada dalam ember. Anak-anak diminta untuk mengamati warna yang dihasilkan dari pencampuran kedua warna tersebut. Guru memandu anak dalam melaksanakan kegiatan tersebut.

6. Pada saat anak-anak melakukan percobaan mencampur warna, Ibu Kasminah sebagai kolaborator mengamati aktivitas siswa dalam melaksanakan kegiatan tersebut. Di akhir kegiatan inti ini, guru menyimpulkan dari percobaan pencampuran warna tersebut.

7. Pada saat istirahat, anak-anak melakukan kegiatan makan bekal dengan dipandu oleh guru. Anak-anak sebelum makan diajak untuk berdoa terlebih dahulu, kemudian diajak untuk cuci tangan bersama-sama dan makan dengan tertib. Setelah selesai, anak-anak bermain APE yang telah disediakan di sekolah.

8. Di awal pelaksanaan kegiatan pertemuan ke dua, guru bercerita tentang peristiwa banjir. Setelah peneliti bercerita peristiwa banjir kepada anak, peneliti mengajak anak untuk mengenal konsep penuh dan kosong dengan mengisi wadah dengan air mineral. Guru mengajak anak-anak untuk berkumpul di sentra yang sudah disediakan dengan duduk melingkar. Guru menjelaskan bahwa dalam kegiatan di sentra ini, anak-anak boleh memilih kegiatan yang disukai dan setelah selesai bisa menuju ke kegiatan yang lain. Jenis kegiatan yang ada terdiri dari tiga kegiatan, yaitu: 1) mengenal konsep penuh dan kosong, 2) membuat perahu dari kertas, dan 3) mencampur warna.

9. Kegiatan pertama, mengenal konsep penuh dan kosong dimulai dengan guru menyediakan botol sebanyak 3 buah dan air mineral. Botol yang pertama tidak diisi, botol yang kedua diisi air mineral setengah, dan botol ketiga diisi air penuh. Kegiatan kedua, anak-anak dibimbing untuk membuat perahu dari kertas lipat dengan dibimbing oleh guru. 
10. Kegiatan percobaan mencampur warna dilaksanakan dengan cara memasukkan pewarna buatan. Kegiatan ini dimulai dengan memasukkan dua warna, yaitu merah dengan kuning untuk dicampur ke dalam dalam air yang berada dalam ember. Anak-anak diminta untuk mengamati warna yang dihasilkan dari pencampuran kedua warna tersebut. Guru memandu anak dalam melaksanakan kegiatan tersebut.

11. Pada saat anak-anak melakukan percobaan mencampur warna, Ibu Kasminah sebagai kolaborator mengamati aktivitas siswa dalam melaksanakan kegiatan tersebut. Di akhir kegiatan inti ini, guru menyimpulkan dari percobaan pencampuran warna tersebut.

12. Setelah selesai anak diajak untuk istirahat. Pada saat istirahat, siswa melakukan kegiatan makan bekal dengan dipandu oleh guru. Anak-anak sebelum makan diajak untuk berdoa terlebih dahulu, kemudian diajak untuk mencuci tangan bersama-sama dan makan dengan tertib. Setelah selesai, anak-anak bermain APE yang telah disediakan di sekolah.

Di awal pelaksanaan kegiatan pertemuan ke tiga, guru bercerita tentang "suara ombak, angin dan suara kebakaran". Setelah peneliti bercerita kegiatan selanjutnya guru menjelaskan bahwa dalam kegiatan di sentra ini, anak-anak boleh memilih kegiatan yang disukai dan setelah selesai bisa menuju ke kegiatan yang lain. Jenis kegiatan yang ada terdiri dari tiga kegiatan, yaitu: 1) membuat gelembung sabun, 2) memasukkan benda ke dalam air, dan 3) mencampur warna.

Kegiatan pertama, membuat gelembung sabun. Sebelum dilakukan, guru menyediakan baskom, detergen, air, dan sedotan minuman serta benang kasur. Kegiatan ini dilakukan dengan mengajak anak untuk membuat larutan sabun dengan mencampurkan dua sendok detergen dengan dua liter air di baskom atau diaduk sampai larut. Setelah itu, anak diminta untuk membuat bentuk segiempat atau segitiga dengan cara menyambung sedotan dengan benang kasur. Setelah itu, anak diberi kesempatan untuk bermain dengan busa dengan peralatan tersebut. Guru menyuruh anak bagaimana membuat gelembung sabun raksasa.

Kemudian jenis kegiatan kedua adalah memasukkan benda ke dalam air. Langkah-langkah kegiatannya adalah guru meminta anak-anak untuk mencoba memasukkan benda yang diduga 
tenggelam seperti batu dan terapung seperti gabus. Kegiatan ketiga, yaitu percobaan mencampur warna dilaksanakan dengan cara memasukkan pewarna buatan. Kegiatan ini dimulai dengan memasukkan dua warna, yaitu kuning dengan biru untuk dicampur ke dalam dalam air yang berada dalam ember. Anak-anak diminta untuk mengamati warna yang dihasilkan dari pencampuran kedua warna tersebut. Guru memandu anak dalam melaksanakan kegiatan tersebut.

Pada saat anak-anak melakukan percobaan mencampur warna, Ibu Kasminah sebagai kolaborator mengamati aktivitas siswa dalam melaksanakan kegiatan tersebut. Di akhir kegiatan inti ini, guru menyimpulkan dari percobaan pencampuran warna tersebut. Setelah selesai anak diajak untuk istirahat. Pada saat istirahat, siswa melakukan kegiatan makan bekal dengan dipandu oleh guru. Anak-anak sebelum makan diajak untuk berdoa terlebih dahulu, kemudian diajak untuk cuci tangan bersama-sama dan makan dengan tertib. Setelah selesai, anak-anak bermain APE yang telah disediakan di sekolah.

Pada kegiatan penutup, guru mengajak siswa untuk beresberes dan recalling. Dalam kegiatan beres-beres ini, siswa diminta untuk mengembalikan tempat bekerja, kembali seperti semula (seperti sebelum kita bekerja) rapi kembali. Sedangkan pada saat recalling, guru dan anak berkumpul. Guru memberikan pesan-pesan pada anak.Selanjutnya gurumelakukan refleksi kegiatan yang sudah dilaksanakan yaitu melakukan tanya jawab seputar kegiatan belajar pada hari ini dari awal hingga akhir pembelajaran. Lalu guru menutup pembelajaran dengan berdoa bersama. Guru mengucapkan salam penutup dan siswa menjawab salam tersebut. Kemudian sebelum meninggalkan kelas siswa berjabat tangan dengan guru.

Dari aktifitas di atas, guru dalam kegiatan pembelajaran yang dilaksanakan Ibu Kasminah selaku kolaborator terlihat pada siklus I ini guru dalam melaksanakan kegiatan pembelajaran sudah sesuai dengan Rencana Kegiatan Harian (RKH). Sebagian besar siswa juga sudah terlihat asyik untuk mengikuti pembelajaran mencampur warna. Anak-anak terlihat cukup antusias dalam mencampurkan warna ke dalam ember air. Namun, masih ada sebagian siswa yang terlihat diam tidak mau melakukan kegiatan tersebut. 
Kemampuan sains siswa dalam siklus I ini diamati dari kemampuan anak untuk menceritakan apa yang terjadi jika warna dicampur. Dari hasil observasi tersebut, kemampuan sains siswa pada siklus I ini mengalami peningkatan apabila dibandingkan dengan pra siklus. Secara rinci hasil observasi tentang kemampuan sains anak pada siklus I ini akan peneliti uraikan pada tabel berikut:

Tabel 4.3

Kemampuan Sains Anak Siklus I

\begin{tabular}{|c|c|c|c|}
\hline Skor & Kategori & Jumlah & Persentase \\
\hline 4 & BSB & 5 siswa & $16,13 \%$ \\
\hline 3 & BSH & 16 siswa & $51,61 \%$ \\
\hline 2 & MM & 9 siswa & $29,03 \%$ \\
\hline 1 & BM & 1 siswa & $3,23 \%$ \\
\hline \multicolumn{2}{|c|}{ Total } & 31 siswa & $100 \%$ \\
\hline
\end{tabular}

Berdasarkan tabel 4.3 tentang kemampuan sains anak pada siklusI di atas dapat dijelaskan sebagai berikut:

1. Kemampuan sains anak yang termasuk dalam kategori Berkembang Sangat Baik (BSB) sejumlah 5 siswa atau sebesar $16,13 \%$.

2. Kemampuan sains anak yang termasuk dalam kategori Berkembang Sesuai Harapan (BSH) sejumlah 16 siswa atau sebesar $51,61 \%$.

3. Kemampuan sains anak yang termasuk dalam kategori Mulai Muncul (MM) sejumlah 9 siswa atau sebesar $29,03 \%$.

4. Bahwa kemampuan sains anak yang termasuk dalam kategori Belum Muncul (BM) sejumlah 1 siswa atau sebesar $3,23 \%$.

Dengan demikian, nilai rata-rata kemampuan sains anakDdi KB Widya Purwacaraka Cabak pada siklus I adalah sebesar 3. Berdasarkan dari interval kategori, skor rata-rata sebesar 3 adalah termasuk kategori Berkembang Sesuai Harapan (BSH).

Berdasarkan dari hasil observasi pada tahap tindakan pada siklus I sebagaimana di atas, dapat diketahui bahwaguru dalam melaksanakan kegiatan pembelajaran sudah sesuai dengan Rencana Kegiatan Harian (RKH). Sebagian besar 
siswa juga sudah terlihat asyik untuk mengikuti pembelajaran mencampur warna. Anak-anak terlihat cukup antusias dalam mencampurkan warna ke dalam ember air. Namun, masih ada sebagian siswa yang terlihat diam tidak mau melakukan kegiatan tersebut. Guru langsung meminta anak tersebut untuk ikutserta mengikuti kegiatan sesuai dengan yang dilakukan oleh temannya yang lain.

Kemudian untuk kemampuan sains anak pada siklus I ini ada peningkatan bila dibandingkan pada pra siklus. Kemampuan sains siswa sudah termasuk dalam kategori Berkembang Sesuai Harapan (BSH) meskipun tidak seluruhnya.

Dari hasil observasi dapat diketahui bahwa kemampuan sains anak yang termasuk dalam kategori Berkembang Sangat Baik (BSB) sejumlah 5 siswa atau sebesar 16,13\%. Kemudian kemampuan sains anak yang termasuk dalam kategori Berkembang Sesuai Harapan (BSH) sejumlah 16 siswa atau sebesar $51,61 \%$. Sedangkan kemampuan sains anak yang termasuk dalam kategori Mulai Muncul (MM) sejumlah 9 siswa atau sebesar $29,03 \%$ dan yang termasuk dalam kategori Belum Muncul (BM) sejumlah 1 siswa atau sebesar $3,23 \%$. Begitu juga dengan nilai rata-rata kemampuan sains anak pada siklus I ini sudah mengalami peningkatan bila dibandingkan pra siklus. Pada siklus I ini nilai rata-rata kemampuan sains anak sebesar 3 yang termasuk kategori Berkembang Sesuai Harapan (BSH).

Hal di atas bahwa kemampuan sains anak pada siklus I ini sudah ada kenaikan bila dibanding dengan pra siklus. Pada pra siklus, kemampuan sains anak yang termasuk kategori Berkembang Sangat Baik dan Berkembang Sesuai Harapan sebesar $35,48 \%$ dan pada siklus I meningkat menjadi $67,74 \%$. Namun peningkatan kemampuan sains siswa pada siklus I ini belum mencapai indikator yang peneliti tetapkan, yaitu secara klasikal kemampuan sains anak yang termasuk kategori berkembang sangat baik (BSB) dan berkembang sesuai harapan (BSH) minimal sebesar $85 \%$.

Terdapat beberapa kendala dalam pembelajaran siklus I ini, yaitu: wadah-wadah air yang disediakan oleh guru masih sedikit, sehingga satu wadah digunakan untuk 10 anak sehingga anak-anak kurang optimal dalam mencampur warna. Selain itu, juga masih ada anak yang tidak mau memilih jenis kegiatan yang disukainya. Melihat dengan kendala yang ada tersebut perlu untuk mengadakan perbaikan skenario 
pembelajaran pada perbaikan pembelajaran siklus II. Perbaikan-perbaikan yang dilaksanakan dalam penyusunan skenario pembelajaran antara lain media yang digunakan sebagai alat bantu ditambah maksimal satu media untuk 5 anak, sehingga kegiatan pembelajaran sains mencampur warna lebih optimal lagi.

Berdasarkan hasil refleksi dari siklus I, penelitian tindakan kelas yang dilaksanakan oleh peneliti belum berhasil. Oleh karena itu, perlu melaksanakan tindakan selanjutnya, yaitu siklus II. Kegiatan ini dimulai dengan peneliti bersama dengan Ibu Kasminah selaku kolaboratormenyusun kembali rencana tindakan siklus II yang tertuang dalam Rencana Kegiatan Harian (RKH) Siklus II.

Skenario pembelajaran siklus II kegiatan intinya sama dengan kegiatan pada siklus I,namun, dalam skenario siklus II ini mengalami beberapa perbaikan/penyempurnaan terutama dalam penyediaan media bermain air mencampur warna sehingga diharapkan dengan adanya penyempurnaan skenario pembelajaran ini, kemampuan sains anakpada tema air, api dan udara dalam pembelajaran lebih meningkat lagi.

Berikut kegiatan-kegiatan dalam tahap perencanaan:

1. Menyusun Rencana Kegiatan Harian (RKH) yang disesuaikan dengan permasalahan pada siklus I.

2. Merancang dan membuat lembar observasi proses pembelajaran dan hasil belajar sains siswa.

3. Merancang dan membuat instrumen evaluasi.

Tahap tindakan siklus II ini, peneliti laksanakan tiga kali pertemuan. Pertemuan 1 hari Senin, 9 Januari 2017. Kemudian pertemuan 2 hari Sabtu, 14 Januari 2017 dan pertemuan 3 dilaksanakan hari Sabtu, 21 Januari 2016 dengan alokasi waktu mulai pukul 07.00-10.30 WIB di KB Widya Purwacaraka Cabak. Pada tahap ini peneliti dengan didampingi Ibu Kasminah selaku kolaborator melaksanakan pembelajaran sesuai dengan RKH yang sudah disiapkan dengan menggunakan kegiatan mencampur warna. Di sini kolaborator bertindak sebagai pengamat dalam pembelajaran.

Adapun langkah-langkah pembelajaran pada siklus II ini sebagai berikut:

1. Guru pada awal kegiatan melaksanakan penyambutan anak. Guru menyambut anak dengan dimulaimengucapkan 
salam "assalamu'alaikum warahmatullahi wabarakatuh". Setelah itu guru mengajak anak untuk berbaris terlebih dahulu di depan kelas. Siswa mengikuti permintaan guru dengan berbaris rapi di depan kelas dengan berdiri berjajar ke belakang. Setelah itu, siswa masuk ke dalam kelas secara bergantian mulai dari depan sampai ke belakang dengan teratur. Siswa dilarang untuk saling mendorong dengan sesama teman. Setelah masuk siswa diminta terus duduk di tempat duduk masing-masing.

2. Guru memandu siswa untuk membaca shalawat dan berdoa do'a bersama. Kemudian dilanjutkan dengan mengabsen siswa satu persatu dan semua siswa hadir semua. Setelah itu siswa melafalkan surah "An Nasr".

3. Pada tahap pijakan awal main pertemuan 1, guru menarik perhatian siswa dengan mengajak siswa untuk menyanyikan lagu "Macam-Macam Rasa": Adapun pada tahap pijakan awal main pertemuan 2, guru menarik perhatian siswa dengan mengajak siswa untuk menyanyikan lagu "Hujan-hujan lagi": Selanjutnya guru meminta siswa untuk mengikuti pembelajaran tema air, api, dan udara pada materi percobaan pencampuran warna.

Peneliti dalam melaksanakan kegiatan inti pada siklus II ini terdiri dari dua pertemuan.

Di awal pertemuan pertama pelaksanaan kegiatan ini, guru bercerita tentang waktu kegiatan dalam satu hari. Setelah itu guru menjelaskan bahwa dalam kegiatan di sentra ini, anakanak boleh memilih kegiatan yang disukai dan setelah selesai bisa menuju ke kegiatan yang lain. Jenis kegiatan yang ada terdiri dari dua kegiatan, yaitu: 1) mencampur air dengan gula, garam dan minyak, dan 2) mencampur warna.

Untuk kegiatan jenis pertama, guru mengenalkan rasa gula dan garam. Setelah itu, anak diajak untuk mencampur air dengan gula, garam dan minyak. Pertama, guru meminta siswa untuk menuangkan gula ke dalam gelas yang berisikan air. Setelah itu, siswa disuruh mengaduk hingga beberapa kali. Setelah selesai siswa disuruh mengamati, apakah gula yang dimasukkan ke dalam air bercampur dengan air atau tidak. Kedua, guru meminta siswa untuk menuangkan garam ke dalam gelas yang berisikan air. Setelah itu, siswa disuruh mengaduk hingga beberapa kali. Setelah selesai siswa disuruh mengamati, apakah garam yang dimasukkan ke dalam air bercampur dengan air atau tidak. 
Kegiatan kedua, yaitu percobaan mencampur warna dilaksanakan dengan cara memasukkan pewarna buatan. Kegiatan ini dimulai dengan memasukkan dua warna, yaitu merah dan kuning untuk dicampur ke dalam dalam air yang berada dalam ember. Pertama, guru meminta siswa untuk menuangkan warna merah dan biru ke dalam gelas yang berisikan air. Setelah itu, siswa disuruh mengaduk hingga beberapa kali. Setelah selesai siswa disuruh mengamati, apakah warna yang dimasukkan ke dalam air bercampur dengan air dan menghasilkan warna baru atau tidak. Guru memandu anak dalam melaksanakan kegiatan tersebut.

Pada saat anak-anak melakukan percobaan mencampur warna, Ibu Kasminah sebagai kolaborator mengamati aktivitas siswa dalam melaksanakan kegiatan tersebut. Di akhir kegiatan inti ini, guru menyimpulkan dari percobaan pencampuran warna tersebut. Pada saat istirahat, siswa melakukan kegiatan makan bekal dengan dipandu oleh guru. Anak-anak sebelum makan diajak untuk berdoa terlebih dahulu, kemudian diajak untuk cuci tangan bersama-sama dan makan dengan tertib. Setelah selesai, anak-anak bermain APE yang telah disediakan di sekolah.

Di awal pertemuan kedua pelaksanaan kegiatan ini, guru mengajak anak untuk mewarnai gambar balon udara. Setelah itu, guru menjelaskan bahwa dalam kegiatan di sentra ini, anak-anak boleh memilih kegiatan yang disukai dan setelah selesai bisa menuju ke kegiatan yang lain. Jenis kegiatan yang ada terdiri dari dua kegiatan, yaitu: 1) membuat mainan topi hujan, 2) mencampur warna.

Kegiatan kedua, yaitu percobaan mencampur warna dilaksanakan dengan cara memasukkan pewarna buatan. Kegiatan ini dimulai dengan memasukkan dua warna, yaitu merah dan biru untuk dicampur ke dalam dalam air yang berada dalam ember. Pertama, guru meminta siswa untuk menuangkan warna merah dan biru ke dalam gelas yang berisikan air. Setelah itu, siswa disuruh mengaduk hingga beberapa kali. Setelah selesai siswa disuruh mengamati, apakah warna yang dimasukkan ke dalam air bercampur dengan air dan menghasilkan warna baru atau tidak. Guru memandu anak dalam melaksanakan kegiatan tersebut.

Pada saat anak-anak melakukan percobaan mencampur warna, Ibu Kasminah sebagai kolaborator mengamati aktivitas siswa dalam melaksanakan kegiatan tersebut. Di akhir 
kegiatan inti ini, guru menyimpulkan dari percobaan pencampuran warna tersebut. Setelah selesai anak diajak untuk istirahat. Pada saat istirahat, siswa melakukan kegiatan makan bekal dengan dipandu oleh guru. Anak-anak sebelum makan diajak untuk berdoa terlebih dahulu, kemudian diajak untuk cuci tangan bersama-sama dan makan dengan tertib. Setelah selesai, anak-anak bermain APE yang telah disediakan di sekolah.

Di awal pertemuan ketiga pelaksanaan kegiatan ini, guru bercakap-cakap menyebutkan nama bulan dalam satu tahun. Setelah itu, guru menjelaskan bahwa dalam kegiatan di sentra ini, anak-anak boleh memilih kegiatan yang disukai dan setelah selesai bisa menuju ke kegiatan yang lain. Jenis kegiatan yang ada terdiri dari dua kegiatan, yaitu: 1) membandingkan waktu pencairan es di dalam air hangat, air dingin, dan tanpa air, dan 2) mencampur warna.

Pertama, membandingkan waktu percairan es di dalam air hangat, air dingin dan tanpa air. Kegiatan ini diumulai dengan mengenalkan es, air hangat dan air dingin kepada anak. Setelah itu, siswa diajak untuk memasukkan es ke dalam air hangat, ke dalam air dingin dan tanpa air. Kemudian anakanak mengamati waktu pencairan es tersebut, mana waktu yang paling cepat mencair dan yang paling lama mencairnya.

Kedua, mencampur warna. Guru menjelaskan bahwa dalam kegiatan ini anak-anak diminta untuk mencampurkan warna primer dengan pewarna buatan merah, kuning dan biru yang sudah disediakan. Kegiatan ini dimulai dengan memasukkan tiga warna, yaitu merah, kuning dan biru untuk dicampur ke dalam dalam air yang berada dalam ember. Pertama, guru meminta siswa untuk menuangkan warna merah, kuning dan biru ke dalam gelas yang berisikan air. Setelah itu, siswa disuruh mengaduk hingga beberapa kali. Setelah selesai siswa disuruh mengamati, apakah warna yang dimasukkan ke dalam air bercampur dengan air dan menghasilkan warna baru atau tidak. Guru memandu anak dalam melaksanakan kegiatan tersebut.

Setelah selesai anak diajak untuk istirahat. Pada saat istirahat, siswa melakukan kegiatan makan bekal dengan dipandu oleh guru. Anak-anak sebelum makan diajak untuk berdoa terlebih dahulu, kemudian diajak untuk cuci tangan bersama-sama dan makan dengan tertib. Setelah selesai, anak-anak bermain APE yang telah disediakan di sekolah. 
Guru dalam kegiatan penutup mengajak siswa untuk beresberes dan recalling. Dalam kegiatan beres-beres ini, siswa diminta untuk mengembalikan tempat bekerja, kembali seperti semula (seperti sebelum kita bekerja) rapi kembali. Sedangkan pada saat recalling, guru dan anak berkumpul. Guru memberikan pesan-pesan pada anak. Selanjutnya gurumelakukan refleksi kegiatan yang sudah dilaksanakan yaitu melakukan tanya jawab seputar kegiatan belajar pada hari ini dari awal hingga akhir pembelajaran. Lalu guru menutup mbelajaran dengan berdoa bersama. Guru mengucapkan salam penutup dan siswa menjawab salam tersebut. Kemudian sebelum meninggalkan kelas siswa berjabat tangan dengan guru.

Berdasarkan dari hasil observasi terhadap aktifitas guru dalam kegiatan pembelajaran yang dilaksanakan Ibu Kasminah selaku kolaborator terlihat pada siklus I ini, terlihat bahwa guru dalam melaksanakan kegiatan pembelajaran sudah sesuai dengan Rencana Kegiatan Harian (RKH). Seluruh siswa juga sudah terlihat asyik untuk mengikuti pembelajaran mencampur warna dengan air. Anak-anak terlihat cukup antusias dalam mencampur pewarna makanan dengan air.

Kemampuan sains siswa dalam siklus II ini diamati dari kemampuan anak untuk mencampur warna dengan air. Dari hasil observasi tersebut, kemampuan sains siswa pada siklus II ini mengalami peningkatan apabila dibandingkan dengan pra siklus dan siklus I. Secara rinci hasil observasi tentang kemampuan sains anak pada siklus II ini akan peneliti uraikan pada tabel berikut:

Tabel 4.5

Kemampuan Sains Anak Siklus II

\begin{tabular}{|c|c|c|c|}
\hline Skor & Kategori & Jumlah & Persentase \\
\hline 4 & BSB & 7 siswa & $22,58 \%$ \\
\hline 3 & BSH & 22 siswa & $70,97 \%$ \\
\hline 2 & MM & 2 siswa & $6,45 \%$ \\
\hline 1 & BM & - & - \\
\hline \multicolumn{2}{|c|}{ Total } & 31 siswa & $100 \%$ \\
\hline
\end{tabular}

Berdasarkan tabel 4.5 tentang kemampuan sains anak pada siklusll di atas dapat dijelaskan sebagai berikut: 
1. Kemampuan sains anak yang termasuk dalam kategori Berkembang Sangat Baik (BSB) sejumlah 7 siswa atau sebesar 22,58\%.

2. Kemampuan sains anak yang termasuk dalam kategori Berkembang Sesuai Harapan (BSH) sejumlah 22 siswa atau sebesar 70,97\%.

3. Kemampuan sains anak yang termasuk dalam kategori Mulai Muncul (MM) sejumlah 2 siswa atau sebesar $6,45 \%$.

4. Bahwa kemampuan sains anak yang termasuk dalam kategori Belum Berkembang (BB) sejumlah 0 siswa atau sebesar $0 \%$.

Berdasarkan hasil diatas kegiatan pembelajaran yang dilaksanakan oleh kolaborator penelitian pada pelaksanaan tindakan siklus II di atas, dapat dilihat bahwa guru dalam melaksanakan kegiatan pembelajaran sains pada materi mencampur warna sudah sesuai dengan Rencana Kegiatan Harian (RKH). Selain itu, hasil pengamatan kolaborator penelitian diketahui bahwa seluruh siswa sudah terlihat asyik untuk mengikuti pembelajaran mencampur warna primer dengan air. Anak-anak terlihat cukup antusias dalam mencampurkan pewarna makanan dengan air. Pada kegiatan yang lain, anak-anak juga cukup antusias dan senang dalam mencampur warna dan mampu untuk menyebutkan hasilnya.

Kemudian dilihat dari kemampuan sains anak pada siklus ॥ sudah meningkat bila dibandingkan dari pra siklus dan siklus I. Kemampuan sains anak meningkat dari siklus I ke siklus II. Kemampuan sains anakpada siklus II ini yang termasuk dalam kategori Berkembang Sangat Baik (BSB) sejumlah 7 siswa atau sebesar 22,58\%. Kemudian kemampuan sains anak yang termasuk dalam kategori Berkembang Sesuai Harapan (BSH) sejumlah 22 siswa atau sebesar 70\%,97. Sedangkan kemampuan sains anak yang termasuk dalam kategori Mulai Muncul (MM) sejumlah 2 siswa atau sebesar 6,45\% dan kemampuan sains anak yang termasuk dalam kategori Belum Muncul (BM) sejumlah 0 siswa atau sebesar 0\%.

Begitu juga dengan nilai rata-rata kemampuan sains anak pada siklus II ini sudah meningkat bila dibandingkan dari pra siklus dan siklus I. Pada siklus II ini nilai rata-rata kemampuan sains anak sebesar 3 yang termasuk kategori Berkembang Sesuai Harapan (BSH). 
Hal ini berarti bahwa kemampuan sains anakpada siklus II ini sudah mencapai indikator yang peneliti tetapkan, yaitu secara klasikal kemampuan sains anak yang termasuk kategori berkembang sangat baik (BSB) dan berkembang sesuai harapan (BSH) minimal sebesar 85\%. Begitu juga dengan nilai rata-rata kemampuan sains anak sudah mencapai skor sebesar 3 yang termasuk kategori Berkembang Sesuai Harapan (BSH). Dengan keberhasilan ini, maka peneliti tidak melaksanakan tindakan pada siklus berikutnya.

\section{SIMPULAN}

Berdasarkan hasil penelitian dan analisis pada bab sebelumnya, dapat disimpulkan bahwa:Kemampuan sains anak di KB Widya Purwacaraka Cabak Pati Tahun Pelajaran 2016/2017 sebelum dilaksanakan tindakan masih rendah. Tingkat kemampuan sains anak sebagian besar termasuk kategori Mulai Muncul (MM) dan Belum Muncul (BM). Dari 31 anak, sebanyak 20 siswa $(64,52 \%)$ termasuk kategori Mulai Berkembang (MM) dan Belum Muncul (BM). Sedangkan kemampuan sains anak sebelum diterapkan metode eksperimen mencampur warna yang termasuk kategori baik, yaitu Berkembang Sesuai Harapan (BSH) dan Berkembang Sangat Baik (BSB) baru sebesar 35,48\%.

Penggunaan metode eksperimen mencampur warna dapat meningkatkan kemampuan sains anak di KB Widya Purwacaraka Cabak Pati Tahun Pelajaran 2016/2017. Hal ini ditunjukkan dari pencapaian indikator keberhasilan yaitu sebagai berikut:Kemampuan sains anak dari pra siklus, siklus I dan siklus II terus mengalami peningkatan. Kemampuan sains anak yang termasuk kategori Berkembang Sangat Baik (BSB) dan Berkembang Sesuai Harapan (BSH) pada pra siklus baru sebesar $35,48 \%$. Kemudian mengalami peningkatan pada siklus I menjadi $67,74 \%$ dan pada siklus II meningkat lagi menjadi 93,55\%. Hal ini berarti bahwa secara klasikal kemampuan sains siswa yang termasuk kategori berkembang sangat baik (BSB) dan berkembang sesuai harapan (BSH) minimal sudah mencapai $85 \%$.

Nilai rata-rata kemampuan sains anak dari pra siklus, siklus I dan siklus II juga terus mengalami peningkatan. Pada pra siklus, nilai rata-rata kemampuan sains anak sebesar 2 yang termasuk kategori Mulai Muncul (MM). Kemudian pada siklus I meningkat menjadi 3 yang termasuk kategori Berkembang 
Sesuai Harapan (BSH). Kemudian pada siklus II nilai rataratanya meningkat lagi menjadi 3 dan termasuk kategori Berkembang Sesuai Harapan (BSH).

\section{REFERENSI}

Ahmad Sabri, Strategi Belajar Mengajar Micro Teaching, Jakarta: Quantum Teaching, 2005.

Anas Sudijono, Pengantar Evaluasi Pendidikan, Jakarta: PT. Raja Grafindo Persada, 2008.

B. Suryosubroto, Proses Belajar Mengajar di Sekolah, Jakarta: Rineka Cipta, 2002.

Departemen Agama RI, Undang-undang dan Peraturan Pemerintah Tentang Pendidikan, Jakarta: Dirjen Pendidikan Islam, Depag RI, 2006.

Departemen Pendidikan Nasional, Standar Kompetensi dan Kompetensi Dasar IPA, Jakarta: Depdiknas, 2006.

Dokumen Profil KB Widya Purwacaraka Cabak Tlogowungu Pati Tahun Pelajaran 2016/2017.

Dokumen Profil KB Widya Purwacaraka Cabak Tlogowungu Pati Tahun Pelajaran 2016/2017.

Dwi Erawati, "Meningkatkan Pengetahuan Sains Anak melalui Pendekatan Eksplorasi Lingkungan Sekitar di TK Pertiwi Kenjer Kelompok B Tahun Ajaran 2012/2013", Skripsi, Semarang: Universitas Negeri Semarang, 2013.

Eko Putro Widoyoko, Evaluasi Program Pembelajaran: Panduan Praktis Bagi Pendidik dan Calon Pendidik. Yogyakarta: Pustaka Pelajar, 2013.

E. Mulyasa, Menjdi Guru Profesional: Menciptakan Pembelajaran Kreatif dan Menyenangkan, Bandung: Remaja Rosdakarya, 2013.

-------, Manajemen PAUD. Bandung: Remaja Rosdakarya, 2012.

Ismail SM, Strategi Pembelajaran Agama Islam Berbasis PAIKEM. Semarang: Rasail, 2008.

J.J. Hasibuan dan Moedjiono, Proses Belajar Mengajar, Bandung: Remaja Rosdakarya, 2009. 
M. Basyiruddin Usman, Metodologi Pembelajaran Agama Islam, Jakarta: Ciputat Pres, 2002.

Muhammad Ali, Guru Dalam Proses Belajar Mengajar, Bandung: Sinar Baru Algensindo, 2002.

Nur Hamiyah dan Moh. Jauhar, Strategi Belajar Mengajar di Kelas, Jakarta: Pustakaraya, 2014.

P. Ratu Ile Tokan, Sumber Kecerdasan Manusia (Human Quotient Resourse), Jakarta: Grasindo, 2016.

Poerwadarminta, Kamus Umum Bahasa Indonesia, Jakarta: Balai Pustaka, 2008.

Purwanto, Statistika Untuk Penelitian, Yogyakarta: Pustaka Pelajar, 2011.

Roestiyah, Strategi Belajar Mengajar, Jakarta: Rineka Cipta, 2008.

S. Margono, Metode Penelitian Pendidikan, Jakarta: Rineka Cipta, 2006.

Saifuddin Azwar, Metode Penelitian, Yogyakarta: Pustaka Pelajar, 2011.

Siti Astuti, "Upaya Meningkatkan Kemampuan Mengenal Konsep Pengurangan Melalui Metode Bermain Peran (Role Playing) Peserta Didik Kelompok B RA Muslimat NU Adikarto III Muntilan Magelang", Skripsi, UIN Sunan Kalijaga, Yogyakarta, 2014.

Slamet Suyanto, Strategi Pendidikan Anak: Pengenalan dengan Matematika, Sains, Seni, Bahasa, dan Pengetahuan Sosial, Yogyakarta: Hikayat Publishing, 2008.

Suharsimi Arikunto, Prosedur Penelitian Suatu Pendekatan Praktek, Jakarta: Rineka Cipta, 2006.

-------, Dasar-dasar Evaluasi Pendidikan. Jakarta: Bumi Aksara, 2012.

Sugiyono, Metode Penelitian Pendidikan: Pendekatan Kuantitatif, Kualitatif dan R\&D. Bandung: Alfabeta, 2006.

--------, Metode Penelitian Bisnis, Bandung: Alfabeta, 2004.

Sumaji, dkk., Pendidikan Sains Yang Humanistis, Yogyakarta: Kanisius, 2003. 
Ana Reknowati dan Sumiyati

Sumiyati, Konsep Dasar Pendidikan Anak Usia Dini dalam Islam, Yogyakarta: Cakrawala Institute, 2014.

Syaiful Bahri Djamarah, Guru dan Anak Didik dalam Interaksi Edukatif, Jakarta: Rineka Cipta, 2000.

Syaifuddin Azwar, Metode Penelitian, Yogyakarta: Pustaka Pelajar, 2011.

Trianto, Model Pembelajaran Terpadu, Jakarta: Bumi Aksara, 2012.

Tri Sujati, "Upaya Meningkatkan Kemampuan Kognitif Anak Usia Dini Melalui Metode Eksperimen Mencampur Warna di TK PGRI Gesengan Cluwak Pati Tahun Pelajaran 2015/2016', Skripsi, Pati: Institut Pesantren Matholi'ul Falah, 2016.

Yuliani Nurani Sujiono, dkk., Metode Pengembangan Kognitif, Jakarta: Universitas Terbuka, 2008.

Zainal Aqib, Penelitian Tindakan Kelas, Bandung: Yrama Widya, 2006.

Zakiah Daradjat, dkk., Metodik Khusus Pengajaran Agama Islam, Jakarta: Bumi Aksara, 2008. 